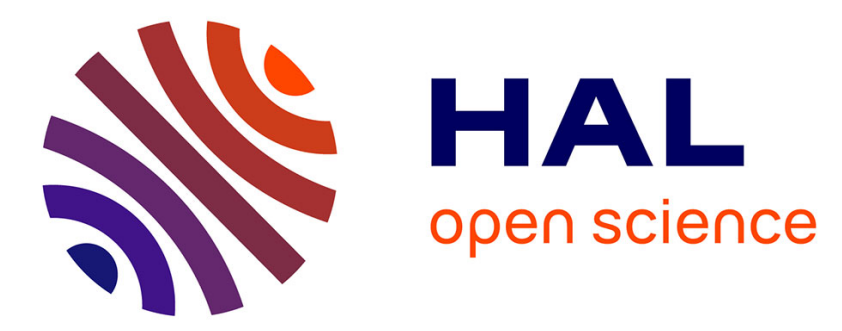

\title{
Contribution of physical modelling to landslide hazard mapping: case of the French Basque coast
}

Marc Olivier, Olivier Sedan, Bernard Monod

\section{To cite this version:}

Marc Olivier, Olivier Sedan, Bernard Monod. Contribution of physical modelling to landslide hazard mapping: case of the French Basque coast. The second world landslide forum, Oct 2011, Rome, Italy. 8 p. hal-00619296

\section{HAL Id: hal-00619296 https: / hal-brgm.archives-ouvertes.fr/hal-00619296}

Submitted on 6 Sep 2012

HAL is a multi-disciplinary open access archive for the deposit and dissemination of scientific research documents, whether they are published or not. The documents may come from teaching and research institutions in France or abroad, or from public or private research centers.
L'archive ouverte pluridisciplinaire HAL, est destinée au dépôt et à la diffusion de documents scientifiques de niveau recherche, publiés ou non, émanant des établissements d'enseignement et de recherche français ou étrangers, des laboratoires publics ou privés. 


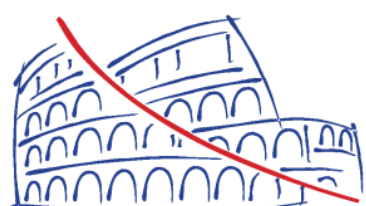

TIHE SECOND

WORLD

LANDSLIDE FORUM

\section{Marc Olivier $^{(1)}$, Olivier Sedan $^{(2)}$, Bernard Monod ${ }^{(1)}$ \\ Contribution of physical modelling to landslide hazard mapping: case of the French Basque coast}

\author{
(1) SGR/MPY, BRGM, Toulouse, France, b.monod@brgm.fr \\ (2) RNSC, BRGM, Orleans, France
}

\begin{abstract}
In the frame of the DO-SMS project (created within the European SUDOE partnership), a new landslide hazard mapping method is experimented on the French "Pays Basque" coast. Based on a physical landslide modelling and integrated into a software named $A L I C E^{\circledast}$, its aim is to propose a quantitative classification of landslide hazard by calculating a probability of occurrence of landslides on each point of the studied area. The method highlights a useful tool to gain time and efficiency in hazard mapping.
\end{abstract}

Keywords Physical modelling, probabilistic approach, landslide hazard, landslide zoning, Pays Basque coast

\section{Introduction}

Mechanical approaches represent a solution for quantitative landslide susceptibility and hazard modelling. These methods consist in, (1) generalizing at regional scale geometrical and geotechnical parameters which contribute to slope stability regarding two types of landslide (i.e. rotational and translational), (2) applying triggering factors to the studied area (water table level and/or seismic stress for example), and (3) calculating a safety factor for each point of the area.

However, as the quantity and the quality of data are generally very heterogeneous at a regional scale, it is necessary to take into account the uncertainty in the analysis. In this perspective, a new hazard modelling method, using a probabilistic approach, is developed and integrated in a software called $A L I C E^{\circledast}$.

This method is experimented for landslide hazard mapping on the French Basque coast. Situated in the South West of France, this region presents high human and economic stakes. Indeed, the Pays Basque littoral has a population density of 504 people $/ \mathrm{km}^{2}$, whereas it is of 81 people $/ \mathrm{km}^{2}$ in average in the South West littoral of France (Mouhali. 2005). Numerous instability problems affect the $42 \mathrm{~km}$ long Basque coast and contribute for a great part to the littoral erosion (Mallet et al., 2005). Landslides are concentrated in a $12 \mathrm{~km}$ long coastal zone between Biarritz and Saint-Jean-De-Luz (Fig. 1) while the rest of the coast is more subject to rock fall phenomenon.

A ground movement (landslides and rock falls) hazard map at a scale of $1 / 20$ ooo already exists on the Basque coast (Nédellec et al. 2005), made by an "expertise" analysis. The works presented in this paper aim at designing a more precise landslide hazard map (1/10 ooo) with a more objective method.

This paper provides a short presentation of the method, developed through the software $A L I C E^{\circledast}$ and the different steps which led to a new landslide hazard map of the French Basque coast area.

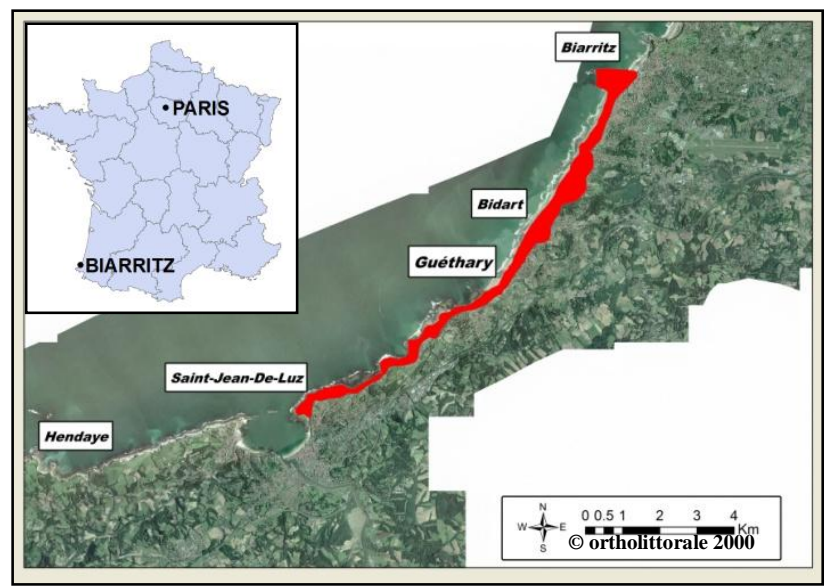

Figure 1 Situation of the studied area (in red) which represents the portion of the coast the most affected by landslide phenomena.

\section{A new landslide physical modelling software: $A L I C E^{\circledR}$}

\section{Principle}

$A L I C E^{\circledast}$, which stands for Assessment of Landslides Induced by Climatic Events, is a software designed to support landslide hazard mapping (Sedan, 2011).

The model is based on a mechanical and geotechnical approach for which the main physical characteristics of the medium are quantified and used by a mathematical model calculating a safety factor (Aleotti \& Chowdhury, 1999). In these models, the spatial variability of the parameters (e.g. mechanical characteristics) has to be known and is handled through GIS software.

The probabilistic approach used in the software allows to take into account uncertainties by giving probabilistic distributions to some of the model parameters (Stillwater, 2007). 


\section{Modelling}

The software uses the Morgenstern and Price method $(1965,1967)$, which is a finite slope stability model based on the equilibrium calculation between slices subdividing the landslide volume. This method is used on regularly spaced topographic $2 \mathrm{D}$ profiles which cover the whole studied area. These profiles are automatically generated by the software using four input raster maps: a Digital Elevation Model (DEM), a slope map, a flow direction map and a flow accumulation map.

Pedological and geological characteristics are taken into account thanks to the altitude maps of the interfaces between each soil layer, the highest limit corresponding to the topographic surface (DEM).

Variability and uncertainty of the geotechnical parameters are introduced in the software by means of probabilistic distributions (normal, uniform, triangular or trapezoid). A distribution is attributed to each soil characteristic (cohesion (c), angle of friction $(\varphi)$ and unit weight $(\gamma)$ ) and for each soil layer.

The safety factor calculation also needs the landslide type (rotational or translational) and its length. These parameters are defined for the whole studied area.

Water table level is set by determining two piezometric maps: one for the maximal water table level and the other for the minimal. The water table is then automatically generated between these piezometric levels by setting a filling ratio.

\section{Software output}

On each profile of the studied area, the software calculates safety factors for several landslide positions (Fig. 2).

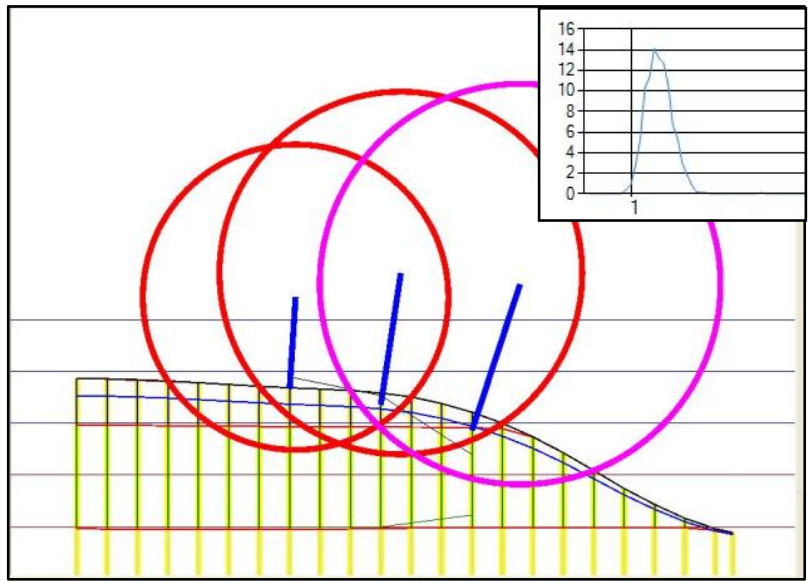

Figure 2 Illustration of the way the software calculates safety factors for several landslide positions (red circles) along a topographic profile on the Basque coast. The pink circle represents the landslide position with the highest probability of occurrence along the profile. The graph in the top right hand corner shows the distribution of calculated safety factors for the pink landslide. (For a detailed description of the cross section, see Fig. 11).

The probability of having the safety factor below than one represents the probability of occurrence of the landslide for a given triggering scenario (i.e. landslide geometry and water table level). The dispersion of the distribution gives the uncertainty of the result.

The calculated probability of occurrence is then attributed to all the pixels of the result raster located on the profile and intersecting the landslide geometry. Thus a pixel receives as many probabilities as landslide positions it is included in. Finally, a map is created, displaying the highest calculated probability of occurrence for each pixel of the studied area.

\section{Application to the Basque Coast}

\section{General context}

\section{Geology}

The French Basque coast displays folded rock units that regionally dip towards the north. Thus, from north-east near Biarritz to south-west near Saint-Jean-de-Luz, geological formations are mainly composed of tertiary sandstone, marly-calcareous and marl formations until Bidart city, and cretaceous flysch with flint, calcareous flysch until Saint-jean-de-Luz city (Fig.3).

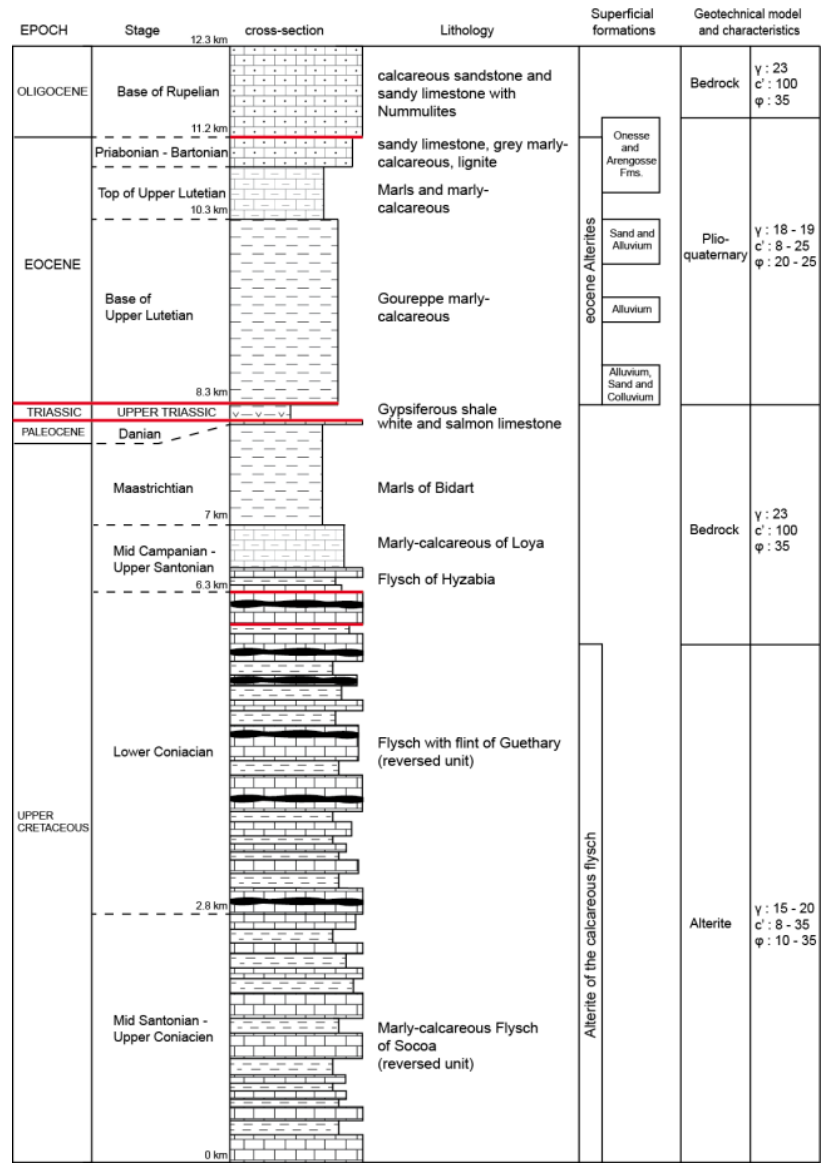

Figure 3 Vertical representation of the geological formations out cropping along the Basque coast and geo-mechanical model associated. The north-dipping rock units are represented in the same order as they are exposed along the coast, from the SW (bottom) to the NE (top). The thickness of the formations represented is proportional to the outcropping thickness along the coast. Main faults are represented in red. Units for the geotechnical parameters are: $\gamma: \mathrm{kN} \cdot \mathrm{m}^{-3} ; \mathrm{c}: \mathrm{kPa} ; \varphi:{ }^{\circ}$. 
A major fault zone is located north of Bidart city, at the base of the tertiary strata. It is responsible for the outcropping of triassic gypsiferous shale and the grinding of rocks around.

The bedrock displays two facies along the coastal cliff: fresh rocks at the base and weathered rocks, called alterite, to the top (few meters from the surface). The alterites are well developed over the eocene units and over the santonian-coniacian flysches.

Plio-quaternary Onesse and Arengosse formations, together with sand formations were deposited over the eocene alterites. Alluvium and colluvium deposits fill in the troughs and the valleys.

The coastal instabilities are concentrated into the alterites and the plio-quaternary formations which present poor mechanical characteristics.

A simplified geological model has been developed, grouping together the coast formations into three "geotechnical units": Plio-quaternary, Alterites and Bedrock (Peter-Borie, 2008, Fig. 3). Hundreds of borehole reports were gathered and interpreted in order to interpolate the altitude of each interface, allowing the creation of maps for the base and the top of each unit.

\section{Hydrogeology}

Water circulations are very complex within the Basque coast reliefs and suffer from a lack of information and studies (Winckel et al., 2004). However, some punctual studies showed that water level was close to the surface at the time of various landslide triggering (Capedeville et al., 1982 ; Peter-Borie, 2008).

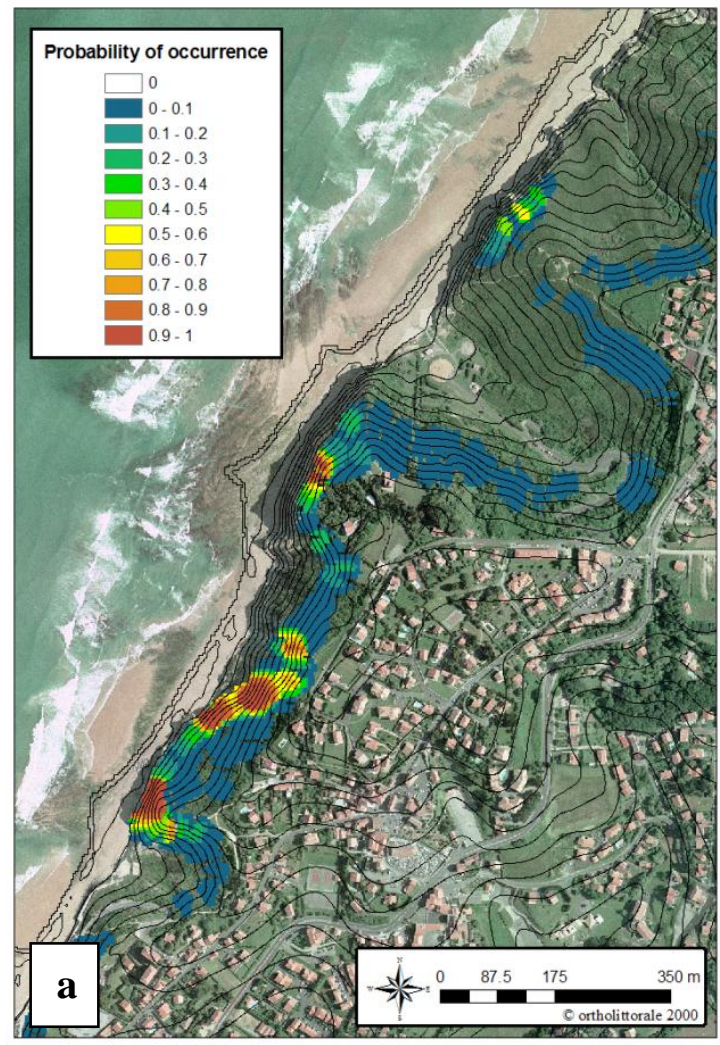

\section{Geotechnical parameters}

Despite the numerous geotechnical studies carried out on Basque coast instabilities, few laboratory tests were made on the materials. Thus some of them had to be determined thanks to expert statements. Ranges of values were then established for each parameter and for each soil unit (right columns, Fig. 3). For the safety factor calculations, triangular distributions of these values, which can be compared to discretized Gaussian functions, were chosen because this type of simple distribution is well adapted when few data are available.

\section{First modelling scenario}

Based on the documents available on the studied area and on a short field visit, a first triggering scenario is established: a constant $2 \mathrm{~m}$ deep water table and $25 \mathrm{~m}$ long landslides are used as input parameters in the software.

The results of this first scenario are presented for the Arretgia beach area (Fig. 4a). A high probability means that the landslide will occur if the triggering scenario is achieved, even if the material has the highest values within the geotechnical characteristic distributions. On the other hand, low probabilities point out stable areas, even for materials with very poor characteristics.

This result map can be used directly in order to evaluate quantitatively the landslide hazard. For a wider accessibility, to integrate public policy documents for example, a "classical" zoning map, with hazard levels (low, moderate, high), is recommended.

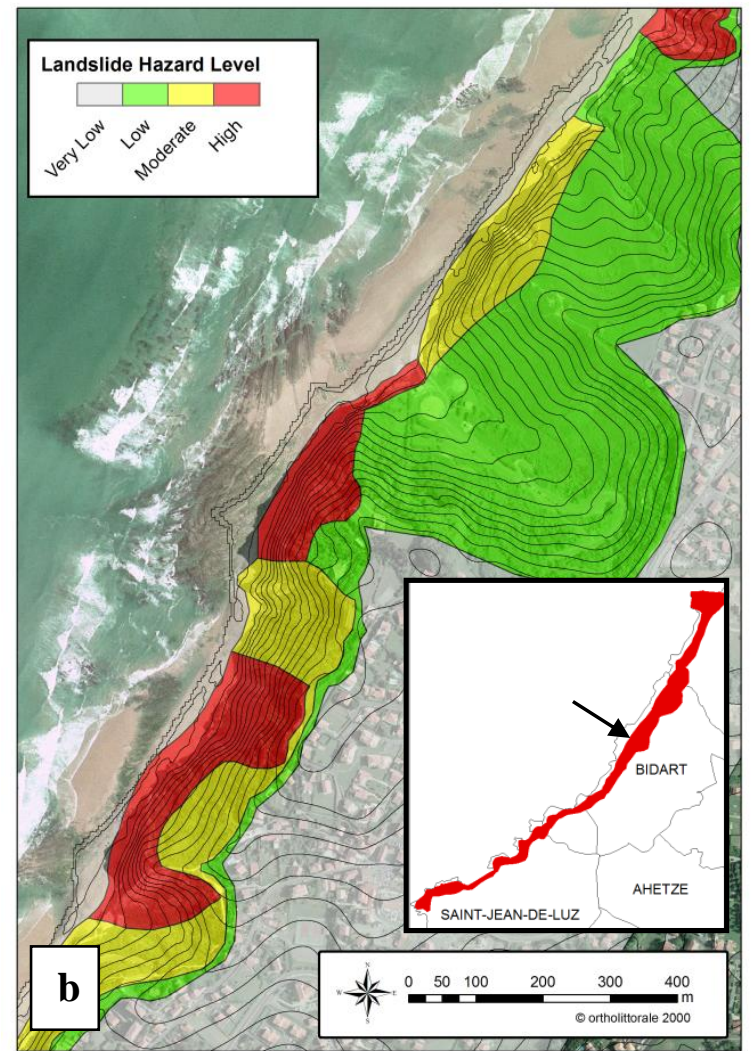

Figure 4 Results of the first modelling scenario on the Erretgia Beach area (a) and corresponding preliminary hazard zoning (b). 
Thus a preliminary zoning of the studied area is realised, based on the software results, satellite images and $5 \mathrm{~m}$ spaced contour lines created from the DEM (Fig. 4 b). Four hazard levels are defined from the probabilities of occurrence: Very Low (o\%); Low $(<10 \%)$; Moderate (10\%-30\%); High (> 30\%).

\section{Field checking}

A second field visit was carried out in order to face the modelling results and the hazard zoning with the ground truth. The whole studied area was observed and commented. In general, a good correlation exists between the modelling results and the reality. However, several areas seem to be under-evaluated by the modelling regarding the existing instability evidences. In some areas, the modelling does not correspond at all to the field observations.

Three sample areas are detailed in this paper: (1) the Erromardie beach presents several zones with various probabilities of occurrence which correspond to the stability context of the area, (2) the Parlementia sector presents some instability evidences which don't fit with the modelling low probabilities and (3) the "Côte des Basques" modelling shows no landslide hazard whereas instabilities are visible nearly all along the area. Erromardie and Parlementia instabilities take place into the alterites of the flysches whereas the Côte des Basques ones are located into marly-calcareous formations.

\section{Erromardie}

Erromardie beach, situated in the city of Saint-Jean-DeLuz, presents many instabilities, from 10 to 40 meter long. The result of the modelling shows many zones with high probabilities of landslide occurrence but also some with lower values (Fig. 5) and this lateral variation is well observed on the field.

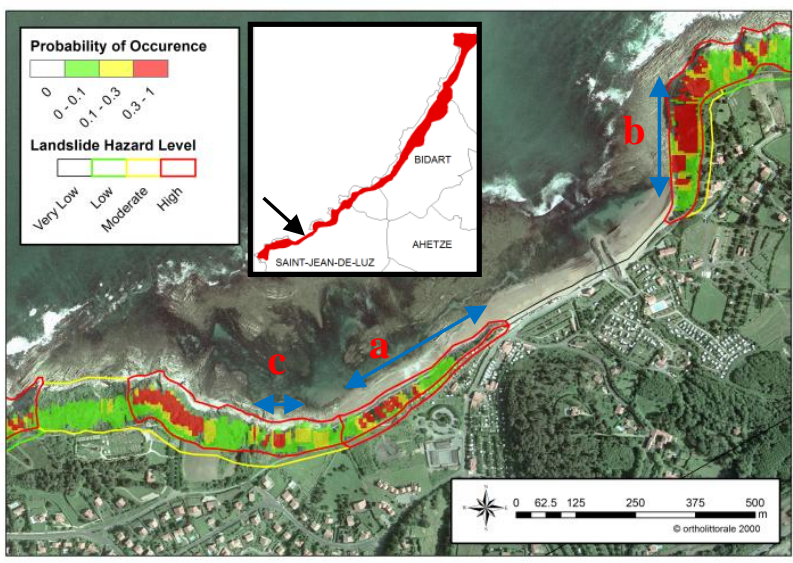

Figure 5 Results of the modelling (probabilities of occurrence) and preliminary hazard zoning map on the Erromardie beach area. The blue arrows show the locations of the photographed banks of Figure 6.

The high probabilities correspond to the sea bank showing either recurrent instabilities (Fig. 6b), or recent landslides (Fig. 6a, 6c) while the low values match with zones without bank (the main sand beach), where the bank slope is less steep or where the bedrock is closer to the surface. Thus the preliminary hazard zoning designed from the modelling results is validated by the ground truth.
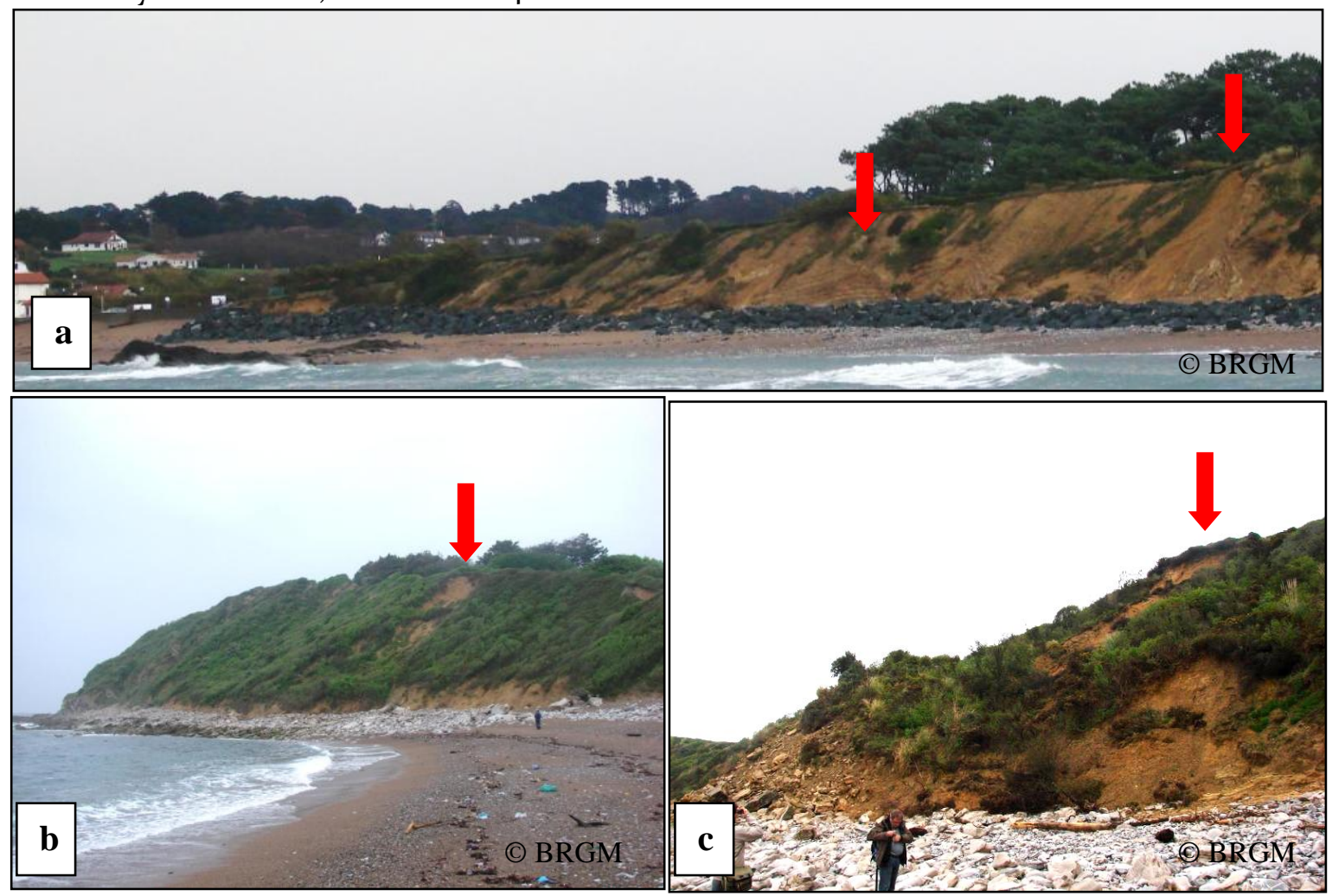

Figure 6 Different instability areas on Erromardie beach. The red arrows point at recent landslides. 


\section{Parlementia}

In this area, the modelling gives a low probability of landslide occurrence (Fig 7) which resulted in a low hazard zone for the zoning map.

However on the field, the sea bank showed signs of instabilities such as tension cracks on the road or on the materials of the bank. Moreover, the slopes situated under the coast houses are comforted by geotextiles and draining blanket in order to avoid infiltration of water within the soil. One of the draining blankets was in construction at the time of the visit (Fig. 8). The need for such soil protections implies a history of instabilities threatening the houses on this site. Here, the preliminary zoning is wrong and have to be modified.

This difference between modelling and reality was encountered several times along the coast. A hypothesis for the bad modelling of these areas is that the landslide size of $25 \mathrm{~m}$ chosen in input is too short. Indeed, many landslides encountered along the coast were longer than $35 \mathrm{~m}$.

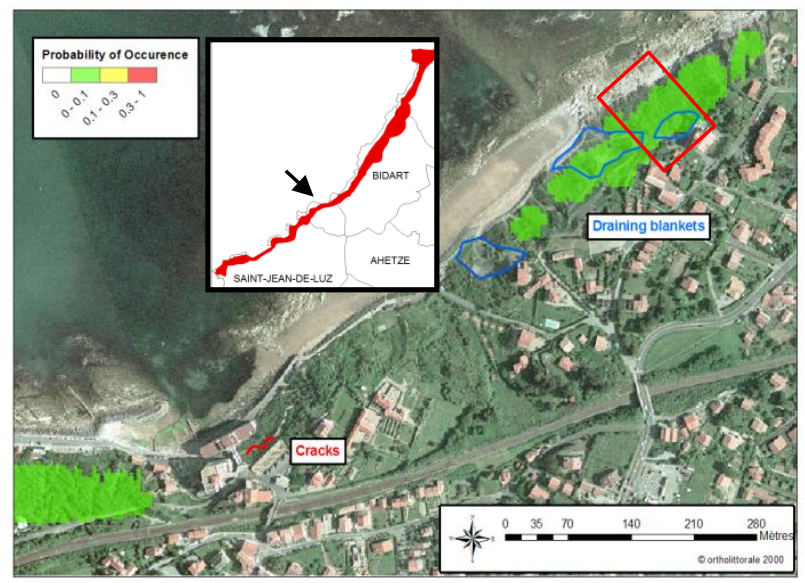

Figure 7 Results of the modelling on the Parlementia area and locations of movement evidences and soil protections observed. The red rectangle represents the localisation of Fig. 8.

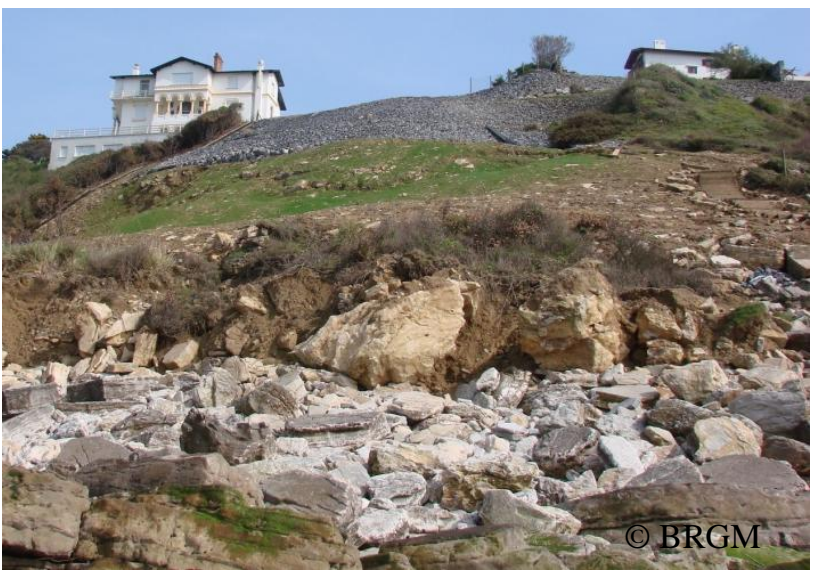

Figure 8 Construction of a draining blanket over slid materials.

\section{Côte des Basques}

The cliffs of the Côte des Basques area are well known for their frequent instability problems and many studies and stabilization works have already been carried out to secure them. Levelling works are still in progress on a part of this area, and the access of the beach underneath is forbidden (Fig. 9). However, the modelling only shows a few low probability areas which are not even matching with the most active landslide zone (Fig. 10).

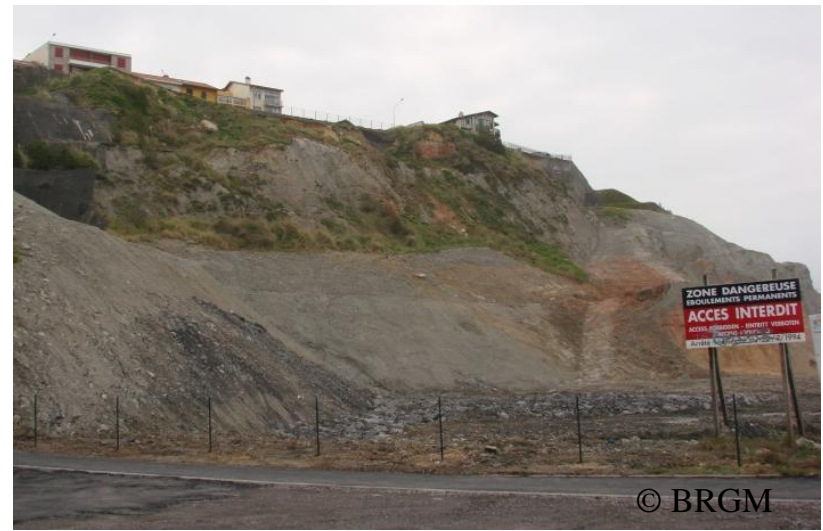

Figure 9 Forbidden area due to frequent landslide occurrence on the South of the Côte des Basques (see localisation on fig. $10)$.

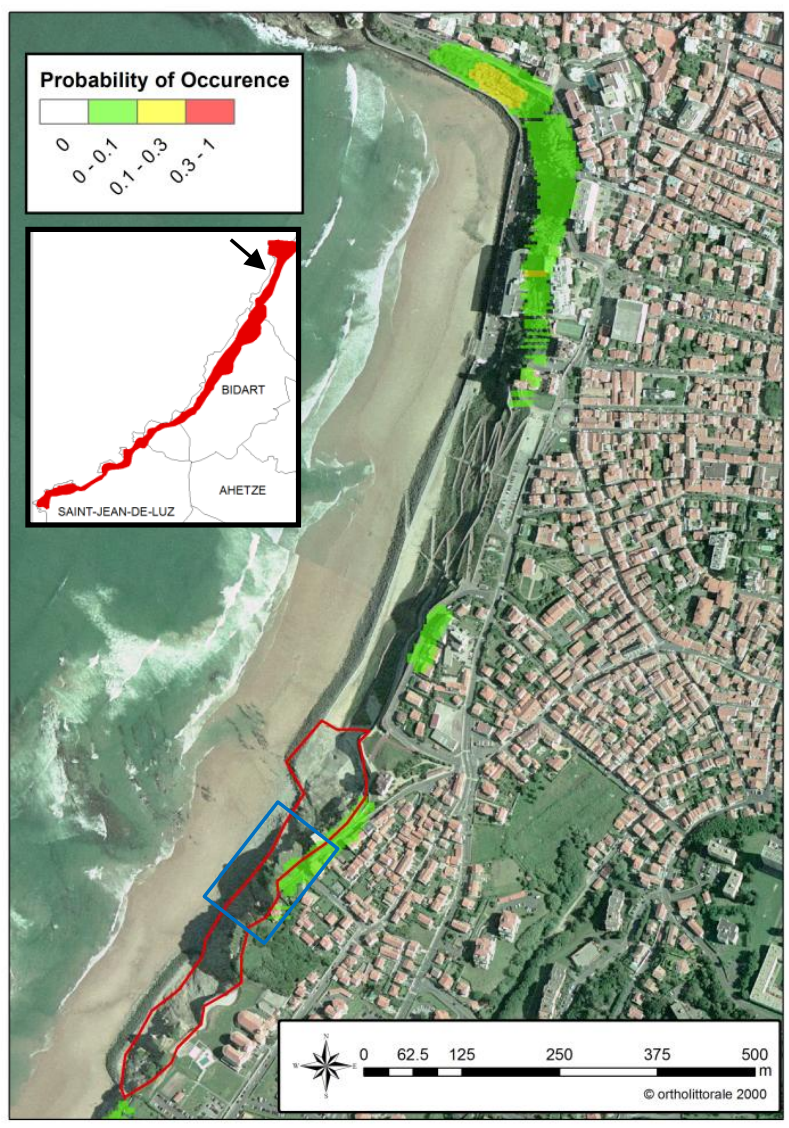

Figure 1o Results of the modelling on the Côte des Basques cliffs. The most active area is highlighted by the red lining. The blue rectangle represents the localisation of Fig. 9.

The problem was identified as coming from the simplified geological model used with the software. Indeed, in this model, the Marly-calcareous rocks of the Cote des Basques cliffs are classified as Bedrock unit. 
Thus, strong mechanical characteristics are assigned to this formation for the software stability calculations (Fig. 3). However, a decompression fringe corresponding to the first meters of rock below the surface displays highly weathered materials (Capedeville et al. 1982). Geotechnical tests on these materials gave much lower characteristics. Thus the modelling is widely overestimating the stability of this area.

Moreover, as the banks are at least 50 meter long, the input landslide size is not adapted to this area.

\section{Second modelling scenario}

Following the field visit and the observations made, a second modelling scenario was established in order to get closer to the reality:

- Input landslide size is raised up to $40 \mathrm{om}$ to be more representative of the instabilities existing in the studied area.

- Water table level is created using a filling ratio of 90\% between the topographic and the sea levels (Fig. 11). Doing so, the water gets closer to the surface while reaching the bottom of the sea bank. This behaviour is close to the ground truth as many smalls water springs were observed in the bottom part of the sea banks.

- The Côte des Basques sector is treated separately from the rest of the coast. The mechanical characteristic values of the Marly-calcareous formations are lowered, corresponding to weathered rock characteristics. For the stability calculation a landslide depth limit of $10 \mathrm{~m}$ is defined based on the estimated thickness of the decompression fringe.

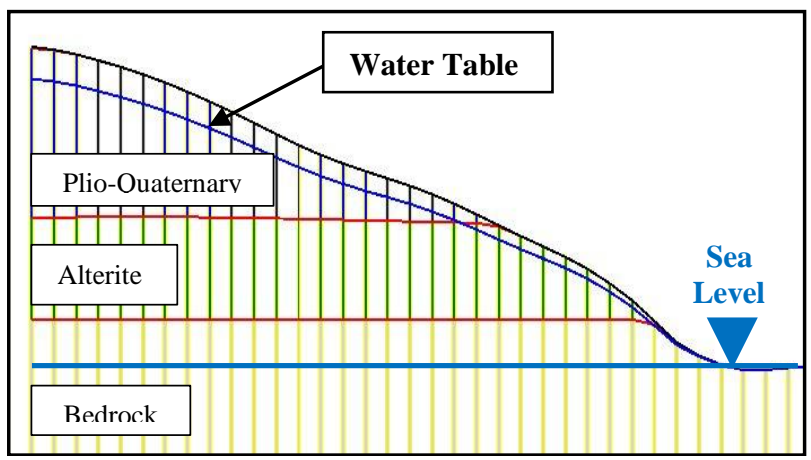

Figure 11 Cross section along the Basque coast showing the topographic surface, the geological model, sea and water table levels. In this example, water table depth is determined as being $10 \%$ of the difference between the topographic and the sea levels.

The results of this second modelling are much more representative of the actual instabilities of the Basque coast than the first, as it can be seen on the Parlementia and Côte des Basques areas (Fig 12). However, some localized sectors still do not match the field observations. It happens mainly in high geological heterogeneities areas (e.g. major fault disturbances, Fig. 3) which are not taken into account in the simplified geological model.

\section{Final landslide hazard zoning}

Based on the new modelling and the field observations, the preliminary landslide hazard map is modified to represent accurately the hazard level on the French Basque coast. In the zones where the modelling is not relevant, a classical expertise approach is used. The final map for the city of Bidart is presented (Fig.13)

A "Very High" hazard level is added for the zoning. It corresponds to zones showing recurent landslide events and can be associated to sectors where the triggering scenario is regularly achieved.

Finally, a regression zone of $20 \mathrm{~m}$ in average is delimited behind the sea bank. The mapping of these areas is based on the results of the software and the study of the historical coast erosion (Peter-Borie, 2008).

As the map was designed at a scale of $1 / 5000$, it has to be used at a maximal scale of $1 / 10000$.
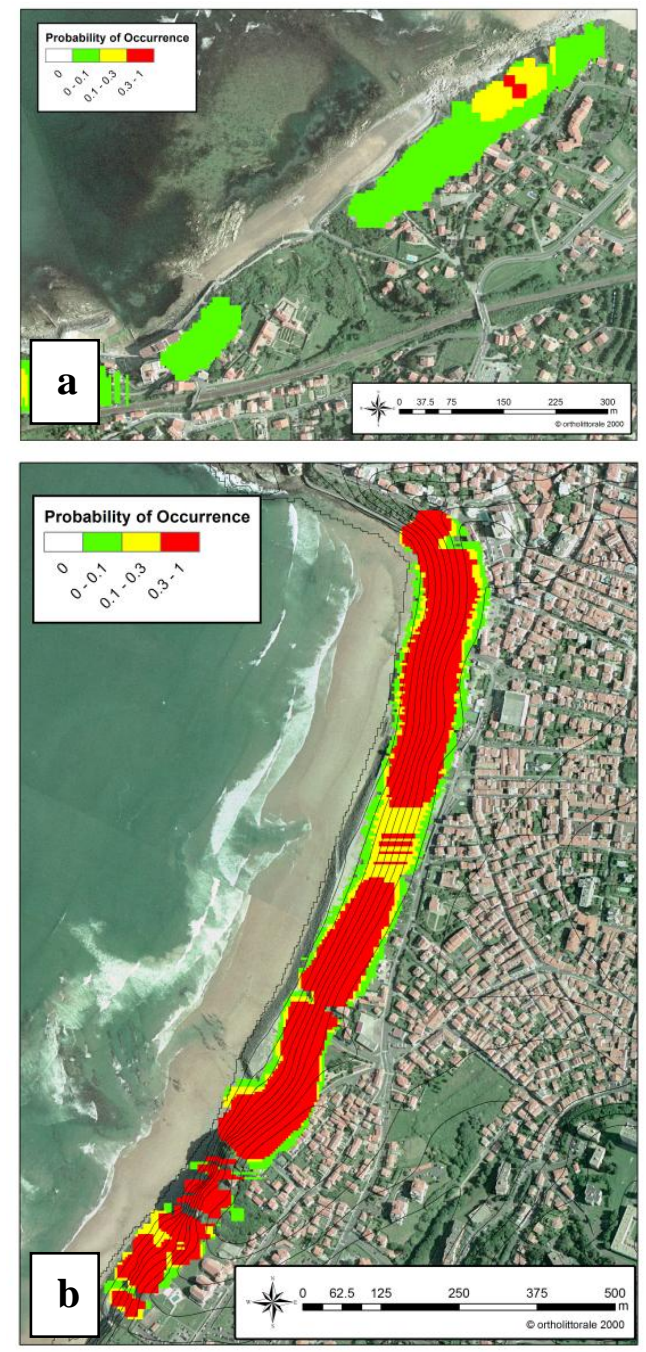

Figure 12 Results of the second modelling for (a) the Parlementia beach and (b) the Côte des Basques cliffs. The displayed probabilities of occurrence correspond much better to the field observations compared to figures 7 and 10. 


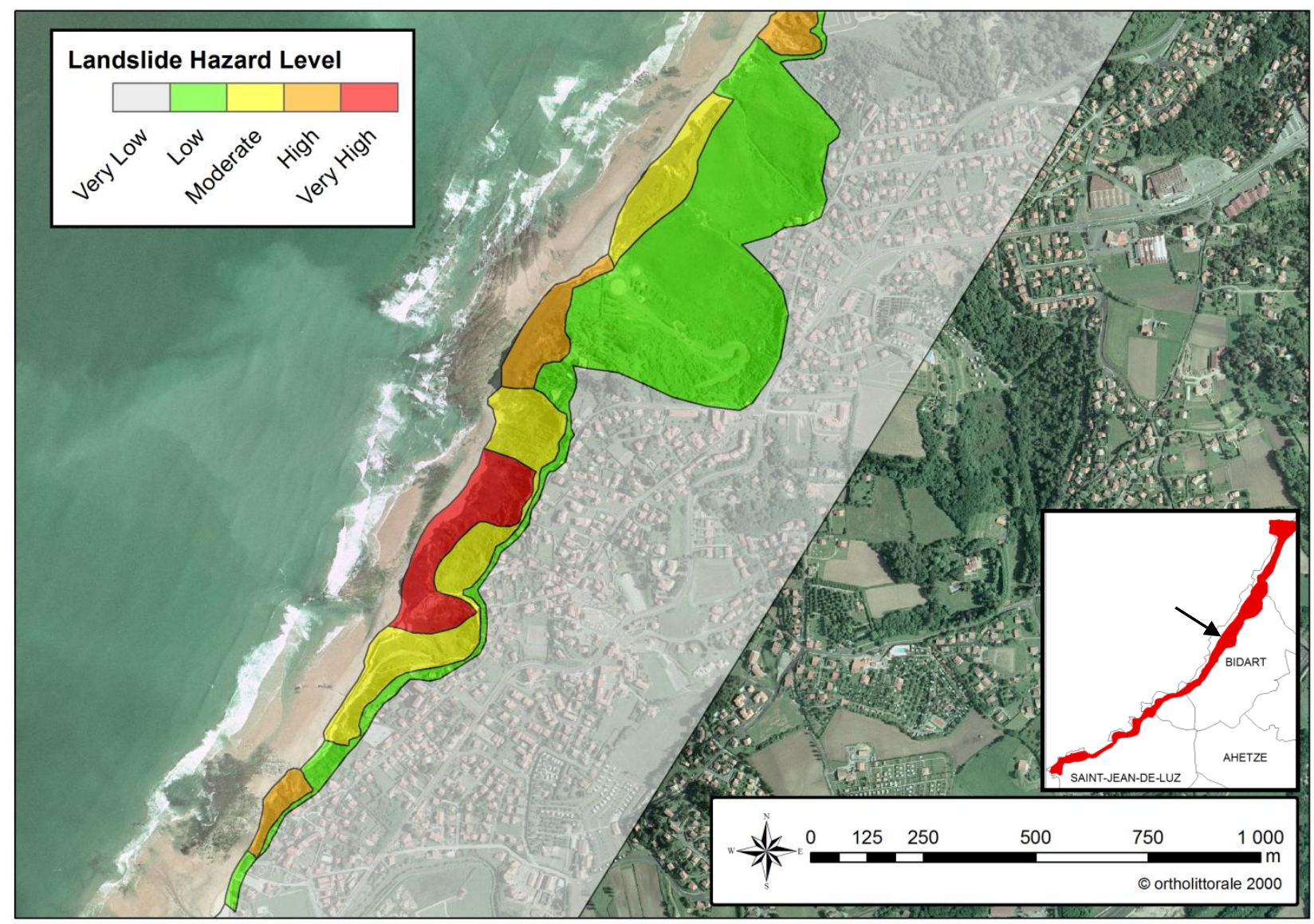

Figure 13 Final landslide hazard map on the city of Bidart.

\section{Conclusions and perspectives}

A landslide hazard map has been designed on the French Basque coast, based mainly on the results of a physical modelling software.

The $A L I C E^{\circledR}$ software provides a useful tool for landslide hazard zoning. It creates a probability of occurrence map for given landslide type and water table level. This map allows a fast spotting of the most sensible areas and a hazard quantification of these areas. However, it still cannot be dissociated from a ground truth approach as shown in the example of the French Basque coast. The main purpose of developing such method is to be able to combine quantitative hazard data with quantitative vulnerability data in order to have a quantitative assessment of the landslide risk.

The difficulties which could be encountered when using this method will probably come from the quantity and quality of data needed. Very few areas are endowed with a $3 \mathrm{D}$ geological model and enough geotechnical characteristics values.

For future works on the Basque coast landslide hazard map, the hydrological modelling should be improved. It could be done using the GARDENIA ${ }^{\circledR}$ rain/flow model (Thiéry, 2003) which simulates the water cycle from rain on a watershed to a phreatic level at a given point or a flow at an exit point. This model involves periodic rainfall and piezometric measurements as well as weather data (e.g. temperature and moisture of the air) in order to highlight the periodic variations of the water table in the coast reliefs.

For the software perspectives, it is planned to generalized the probabilistic approach on other parameters than geotechnical characteristics, like landslide geometry, soil layer thickness or water table level. $A L I C E^{\circledR}$ should also be combined with a landslide material propagation software in order to create a complete landslide modelling tool.

\section{Acknowledgments}

The authors would like to thank Christian Mathon who accepted to share is strong knowledge on the French Basque coast and who provided many useful advices all along the study. We express our gratitude to José Darrozes for both leading the DO-SMS project and reviewing this article providing very useful suggestions. We also wish to thank Sandrine Aubie for accompanying us on our first field visit on the Basque coast and Anais Hoareau for her precious help in the handling of the numerical data. Finally, the authors express their gratitude to all the partners of the DO-SMS project who showed their interest in our work and shared their point of view and experience on difficult parts of our researches. 
The DO-SMS project is financially supported by the STC SUDOE through the Interreg IV B funding.

The geological model and some other numerical data on the French Basque coast were provided by the OCA organisation.

\section{References}

Aleotti P, Chowdhury R (1999) - Landslide hazard assessment: summary review and new perspectives. Bull. Eng. Geol. Env., 58: 21-44

Capedeville J.P., Combe M., Dubreuilh J., Teissier J.L. (1982) Géologie et hydrogéologie de la falaise de la côte des basques et de son arrière-pays. Schéma de principe pour le drainage. 82 SGN 562 AQI, 36p.

Mallet C., collaboration Aubié S., Capdeville, J.P., Dubreuilh J., Genna, A., Lamarque C., Nédellec J.L., Mathon C., (2005) Synthèse des études réalisées sur les instabilités de la côte basque entre 2001 et 2005. BRGM/RP-54012-FR, 32p.

Morgenstern, N.R., and Price, VE. 1967. A numerical method for solving the equations of stability of general slip surfaces. Computer Journal, 9: 388-393.

Morgenstern, N.R., and Price, VE. 1965. The analysis of the stability of general slip surfaces. Geotechnique, 15(1): 79-93.

Mouhali K., (2005) Littoral aquitain, diagnostic de territoire. INSEE Aquitaine, 45p.

Nédellec J.L., Zornette N., Mathon C., collaboration Aubie S. et Imbault M.H., (2005) Evaluation et cartographie de l'aléa mouvements de terrain sur la côte basque. - Observatoire de la Côte Aquitaine - BRGM/RP-52783-FR rapport final, 41p.

Peter-Borie M., (2008) - Les massifs rocheux du Crétacé supérieur du Labourd occidental: processus d'altération et instabilités littorales. Thèse de doctorat, Université Bordeaux 1, 342p.

Sedan O., (2011) - Logiciel ALICE version 7 - Guide Utilisateur. BRGM/RP-60004-FR, 32p.

Stillwater Sciences. (2007) Landslide Hazard in the Elk River Basin, Humboldt County, California. Final report. Prepared by Stillwater Sciences, Arcata, California for the North Coast Regional Water Quality Control Board.

Thiéry D. 2003 ; Logiciel GARDÉNIA version 6.0 - Guide d'utilisation, In French (GARDÉNIA software release 6.0 User's guide), BRGM/RP-52832-FR.

Winckel A., Petitjean J., Borie M., Mallet C., Aubié S. (2004) - Etat des connaissances hydrologiques et hydrogéologiques de la côte basque. BRGM/RP-53372-FR, 113p. 